\title{
The effectiveness of implementing credit hours co-curricular courses in Sultan Idris Education University
}

\begin{abstract}
This study aims to identify the role of Co-curriculum Centre in implementing the cocurricular courses for the Bachelor of Education (ISMP) students of Sultan Idris Education University. The survey's design uses questionnaires on the effectiveness of co-curricular courses of UPSI $(\alpha=.80)$ on 811 respondents of eighth semester students. The findings show that all sections are given good feedbacks by the students and state that they agree that the Co-curriculum Centre provides knowledge and experience which are useful to be applied during teaching practice. The highest mean score is co-curriculum content item $(\mathrm{m}=3.68)$, lecturer of the co-curricular course item $(\mathrm{m}=3.37)$, support officer of co-curriculum center item $(\mathrm{m}=3.31)$ and teaching aids $(\mathrm{m}=3.15)$. Through ANOVA, the comparison between the four items shows significant differences of $p<.05$. The factor of the content of co-curricular courses offered $\mathrm{F}(3,807)=12: 59, \mathrm{p}=.000$ and co-curricular course lecturer factor $\mathrm{F}(3,807)=$ $4: 49, p=.004$. While the teaching aids factor and the officers of Co-curriculum Center did not show a significant difference. The findings show that the co-curricular courses are very beneficial to the ISMP students in guiding them to implement co-curricular activities during the teaching practice in schools. Nevertheless, the Co-curriculum Centre should always be ready to provide beneficial courses, experienced lecturer, sufficient facilities and teaching aids, and dedicated officers.
\end{abstract}

Keyword: Co-curricular course; Co-curriculum centre; Course content; Teaching aids 